\title{
Analysis of the Implementation of the Islamic Contract Principle on Hajj Fund Management By Hajj Fund Management Agency (BPKH)
}

\section{Acep R Jayaprawira and Abdussalam}

Magister Ekonomi-Islamic Economics and Finance (IEF)-Universitas Trisakti

\section{Abstract}

The Indonesian Hajj funds collected at the end of 2017 According to the data from the Ministry of Religion amounted to Rp96.85 trillion, plus the Ummah Endowment Fund of 3:05 trillion, the total amount was indeed Rp 99.9 trillion. Based on the mandate of Law No. 34 of 2014 concerning the Financial Management of Hajj, the management has been transferred from the Ministry of Religion of the Republic of Indonesia to the Hajj Financial Management Agency (BPKH). This study is a contract for the management of the hajj funds in the Islamic perspective. The methodology approach used is descriptive qualitative analysis. The results showed that there was a contract that was

Corresponding Author: Acep R Jayaprawira alam_sidogiri@yahoo.com

Received: 16 September 2019 Accepted: 28 September 2019 Published: 31 October 2019

Publishing services provided by Knowledge E

(c) Acep R Jayaprawira and Abdussalam. This article is distributed under the terms of the Creative Commons

Attribution License, which permits unrestricted use and redistribution provided that the original author and source are credited.

Selection and Peer-review under the responsibility of the ICEMA Conference Committee.

\section{G OPEN ACCESS} most effective in receiving the funding activity by BPKH was the ljarah Maushufah Fid Dzimmah contract. With this agreement can answer the polemic around the contract between the pilgrims with BPKH. It is also known that the law of investing funds is possible / legal, as long as it is based on the that have been recommended by the DSN fatwas and channeled to the business sector of the business that can generate profits and lawfully in sharia way, free from maysir (speculative), usury (interest / usury), and gharar (uncertainty).

Keywords: hajj fund, muamalah, IMFD, hajj financial management, agency.

\section{Introduction}

One of the pillars of Islam is to perform the Hajj for those who are able. This fifth pillar apparently received a tremendous response from the Indonesian Muslim community. According to data released by the Ministry of Religion that the interest of the Indonesian people to go to the holy land has always increased from year to year.

Before 2013, the development of the number of pilgrims from year to year in Indonesia has always increased. After 2013, the Saudi Arabian Government carried out renovations and expansion of the recitation site so that a policy of reducing the hajj quota of $20 \%$ appeared for all countries (Hajj Evaluation Report, 2013: 5). Countries Indonesia before 2013 get Haj quota from Saudi Arabia averaged almost 200 thousand congregations. Then in 2013, the number of pilgrims who departed for the Holy Land only 154547 
pilgrims, in 2014 Indonesia sent a total of 154467 pilgrims, in 2015 as many as 155 200 pilgrims, and by 2016 as many as 168800 pilgrims. The last in 2017 has been normalized again to around 211 thousand worshipers. This amount is a normal amount for Indonesia based on the ratio agreed upon by OIC countries. Then it was added by Saudi King Salman Bin Abdul Aziz for 10,000 congregations because there were incidents of crane accidents in 2015, bringing the total to 221 thousand. [1]

The legal basis for the implementation of the pilgrimage in Indonesia is Law Number 13 of 2008 concerning the implementation of the Hajj. According to Subadi (2013) Hajj services in Indonesia are in accordance with the Act. However, Hajj services in Malaysia are far better than services in Indonesia (Kalono, Setiaji, 2010). This is because the details of the pattern of management of the Hajj pilgrimage are not yet detailed. Meanwhile, with the increasing allocation of the Hajj fund each year and the longer waiting time, it is necessary to arrange a professional, permanent Hajj fund and can provide a mandate to the Ministry of Religion to carry out the financial management.

Hajj fund management is a serious matter that needs to be observed and improved to support the implementation of the Hajj which is more professional, trustworthy, transparent and optimal. Moreover, the number of Indonesian citizens who register to perform the pilgrimage from year to year continues to increase. Though the hajj quota set by the Kingdom of Saudi Arabia is very limited. This resulted in an increase in the number of pilgrims waiting (waiting list). The impact later, the increase in the waiting pilgrims caused a large amount of pilgrims to accumulate funds. To end of year 2017 , the accumulated funds in the Ministry of Religious Affairs Hajj has reached approximately USD 99, 9 trillion. (BPKH Strategic Plan 2018-2022).

The amount of funds is very significant, because since 2004 the Ministry of Religion has implemented a system of early deposit payments (down payment) for the cost of organizing the pilgrimage $(\mathrm{BPIH})$. S Before the era $\mathrm{BPKH}$ stand as it is today, BPIH deposit stays in the Receiving Bank deposit (CPM) only. The hajj funding stays in the Bank Indonesia without the benefit of added value, but only a guaranteed conversion to US Dollar. In 2006, BPIH began to be managed in the form of demand deposits, deposits and savings in commercial banks. After that, since 2009 the Hajj fund has also begun to be invested in the Indonesian Hajj Fund Sukuk (SDHI). Investments in Sukuk provide greater benefits than deposits, so that the value of benefits for pilgrims can increase. Based on data from the Directorate General of Debt Management (DJPU), the development of SDHI has always been increasing, along with the data on its development. 
120.00

100.00

80.00

60.00

40.00

20.00

0.00

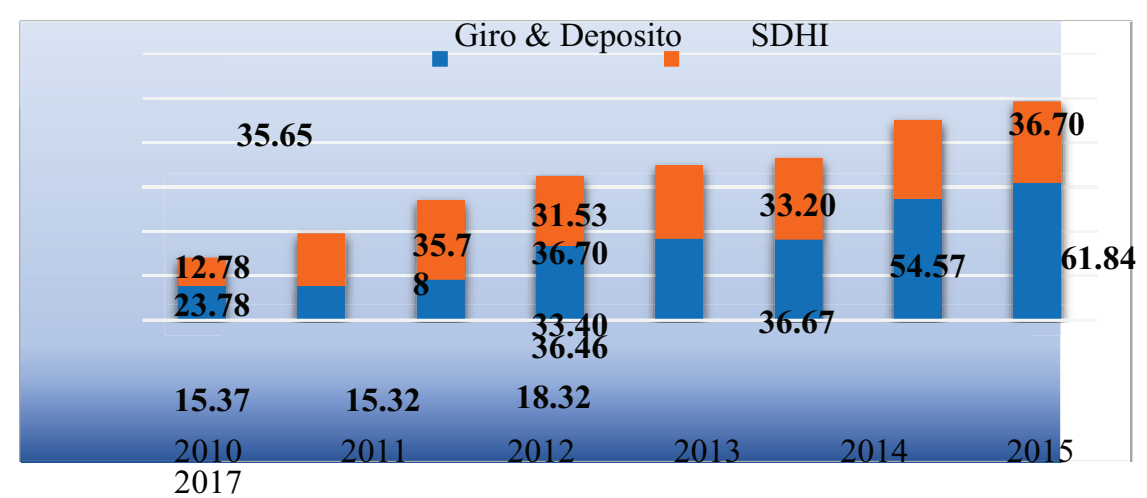

Figure 1: Placement of Hajj Funds 2010 - 2017 (Source: djpu.depkeu.go.id and haji. Ministry of Religion.go.id, (processed by Author).).

It is known from the graph above, that the outstanding SDHI value per December 2017 is IDR 36.7 trillion. Since the first publication of SDHI in 2009 the amount of hajj fund placement in sukuk amounted to IDR 2.7 trillion, increased to IDR 35.78 trillion in 2012. Placement of Hajj funds in sukuk decreased by the end of 2013 to IDR 31.53 trillion, because the sukuk value was IDR 4.25 trillion is due in May 2013 and is not roll over (but placed back on deposits). In 2016 , the placement of investments in securities amounting to Rp35, 65 trillion. Apart from sukuk, the investment placement of the Hajj fund is also done through deposits. Increased value of deposit placement in 2013 due to an increase in banking returns and the enactment of the LPS guarantee program for congregational funds. [2] In addition, during this period there was a transfer of cash hajj funds to banking products. In fact, at the end of the 2016 period, the value of the Hajj funds placed on deposits rose dramatically to Rp54.57 trillion.

BPIH optimization step is realized by the presence of Act 34 Year 2014 in the era of President Susilo Bambang Yudhoyono, which mandates the establishment of Financial Management Board Haji (BPKH). After the BPKH Board of Trustees and Implementing Agency was appointed by President Joko Widodo on July 26, 2017, the management of the Hajj fund then became a hot issue that was widely discussed by the public, both in seminars, bahtsul masail ad-Diniyah, as well as on social media. This is related to the statement of the President of the Republic of Indonesia, Mr. Ir. Joko Widodo to use the existing Hajj funds for infrastructure development in the country. The statement spontaneously invited the pros and cons of public fairly sharply. There are those who support a number of arguments, and many also oppose the use of Hajj funds for infrastructure development. But if mapped Retained Earnings general, the disputes that arise can be grouped in two basic problems early, namely the problem of jurisprudence and legal aspects of the underlying problems. Jurisprudence is concentrated on discussions 
around the aspects of sharia or muamalah and the clarity of the use of the Hajjfunds to be invested in any sector and any business activities. While the issue of legal aspects is very closely related to the underlying regulations.

From the description above background, the authors are interested in discussing more about the legal aspects and issues of sharia in the management of financial funds Hajj in Indonesia, as well as the issue of regarding law the terms of hajj funds invested in perspective Islamic jurisprudence.

\section{Literature Review}

\subsection{Operational of Hajj Registration in Indonesia}

In organization worship pilgrimage, Congregation have two type option worship h aji which has been determined by the Ministry of Religion of the Republic of Indonesia, namely regular Hajj and special Hajj services. To carry out regular Hajj takes approximately 40 days and the $\mathrm{ONH}$ Hajj plus takes time less more 25 days. In the regular Hajj registration process, Islamic Banks have a very strategic position. In addition to functioning as a fund collector from the congregation, Islamic banks can play a role as a driver for increasing the number of Hajj registrants annually. While the majority of Hajj Pilgrims from Indonesia are regular Hajj Pilgrims so that good coordination is needed from all relevant institutions in the implementation of the Hajj.

Whereas there is a special Hajj registration process, all the obligations of the congregation are facilitated by PIHK (Special Hajj Organizers) or generally in the form of travel bureaus so that PIHK has a very strategic position and has considerable influence in special Hajj services. The Association like Himpuh and Amphuri is also has a strategic role in organizing a special Hajj by entering data on accommodation, transportation and catering to SISKOHAT. That way, the association gets full access to the holding of a special Hajj and requires full support from the PIHK.

\subsection{The Contract Principles in Islamic Jurisprudent}

According to Muhammad Yusuf Musa (2014), Muamalah Fiqh is the rules of Allah that are followed and adhered to in living in a society to protect human interests.[3] In other words, muamalah Fiqh is all the rules created by Allah SWT. for govern the order of life relationship between humans and other humans. In the context of the problem muamalah is always related to various activities of daily life. The discussion 
of muamalah, especially in economic matters, of course will often be found in an agreement or contract. Basically a contract is not different from a transaction (handover). All commitments made by two or more parties must not deviate and must be in line with the will of the Sharia. There must be no agreement to deceive others, prohibited transactions and agreements to kill someone.

\subsection{Contracts Sharia Principles}

The transactions in Islamic sharia must be based on the following principles:

\subsubsection{Brotherhood (ukhuwah)}

This means that sharia transactions uphold the value of togetherness in obtaining benefits, so that a person may not benefit from the loss of others. This principle is based on the principle of mutual know (ta'aruf), understanding (tafahum), mutual help (ta'awun), guarantee full (takaful), mutual and mutually affiliated synergize (tahaluf).

\subsubsection{Justice ('adl)}

It means always putting something only to those who have the right and in accordance with the reality of this principle in the frame of muamalah rules is to forbid the existence of elements:

1. Usury / interest in all forms and types, both usury nasiah or fadhl, usury itself is translated as an addition to the principal receivables required in the transaction of goods, including similar exchanges in cash and tough and non-cash in kind.

2. Injustice, both to oneself, others or the environment. Injustice is translated as giving something that is not according to the size, quality and tempo to take something that is not his right and treat something that is not in his place / position.

3. Maysir / gambling or being speculative and not related to productivity.

4. Gharar / an element of vagueness, manipulation and the exploitation of information and the absence of certainty in the implementation of the contract, such as: uncertainty in the submission of contract objects, or exploitation because one of the parties does not understand the contents of the agreement.

5. Tadlis / elements of fraud, both fraud in terms of quality and quantity of goods transacted. Such as declaring the quality of goods produced, even though the goods 
are fake, or declaring the quantity of an item to be 500 units, even though the actual number is only 490 units.

6. Talaqqi ar-Rukban (intercept merchandise of others in the middle of the road). The goal is so that the owner of the merchandise does not know the actual price, and the buyer can take maximum advantage by utilizing the seller's ignorance.

7. Unclean / all the elements expressly prohibited in holy Qur'an and Al-Hadith, both in the goods / services or related operational activities.

\subsubsection{Benefit (maslahah)}

This means that all forms of goodness and benefits are worldly and spiritual, material and spiritual, as well as individual and selective. Benefit must fulfill two elements, namely: halal (obedient to the provisions of sharia) and thayyib (bring good and useful).

\subsubsection{Balance (tawazun)}

This means that the balance between material and spiritual aspects, between the private and public aspects, between the financial sector and the real sector, between business and social and between aspects of utilization and preservation. Islamic transactions do not only pay attention to the interests of the owner but pay attention to the interests of all parties so that they can feel the benefits of an economic activity.

\subsubsection{Universalism (syumuliyah)}

This means that the essence can be done by, with and for all parties concerned without distinguishing ethnicity, religion, race, and class, according to the spirit of the universal freedom (rahmatan li alamin).

\subsubsection{Willingness (al-Ridhâ)}

Based on this principle, all forms of contract must be made because of self-willingness, not because of compulsion or coercion. Because willingness between parties who are involved is a prerequisite for the realization of all transactions. Thus, if this principle is not fulfilled, then the contract can be considered null or invalid, and if the condition continues to be carried out then it means to eat something in a vanity way (al-akl bi al-bâtil). 


\subsubsection{Equality or equality (al-Musawah).}

This principle provides the basis that both parties who are carrying out an agreement contract have the same and equal position. So, when determining their respective rights and obligations based on the principle of al-Musawah.[4]

\subsection{Rule Jurisprudence on Government Investment Policy}

There are some rules of jurisprudence explaining there is proper investment in a business that is lawful, because it is seen as a form of muamalah ibahah (allowed). Also some Jurisprudence rules regarding the policy of a leader dilemma between two things that are opposite in making their decisions, then in this case he must take the most troubled and the least dangerous.

The First Rule,

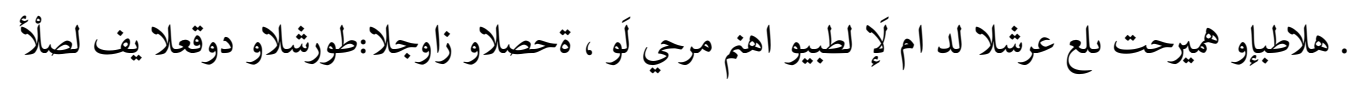

"Basically, the legal origin of all forms of contract muamalah and treaties, is permissible and lawful unless there is the argument of law which forbids and cancel it." [5]

Second Rule,

$$
\text { امهفأ باكتراب اررض امهظعأ يعور ناتدسفم ضراعت اذا }
$$

"If there are two conflicting things going on, then you must pay attention to the greatest impact of the damage by doing the least damage." [6]

Third Rule,

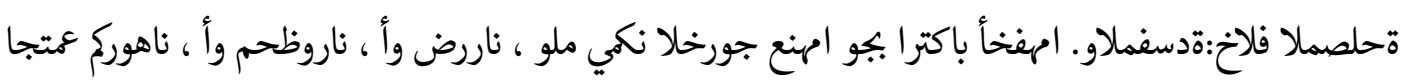

If two congregations of makruh or haram gather, or two things that are equally dangerous, and cannot get out of both, then the law is obligatory to take the lightest impact of both. The meaning of mafsadah (damage) is the opposite of maslahah. [7]

In the Dictionary of al-Wasith mentioned: Al-Mafsadah is dharar (danger). Mafsadah can be said for everything that can cause damage, such as vanity, playfulness and the like. Abu 'Itahiyyah said, said, that; "The rules and regulations of Islamic sharia are to benefit and reject damage. Whereas the original law of every benefit is to make it happen. Conversely, the original law of damage is to avoid it or reject it, or prevent it. Thus, when two benefits occur are conflicting and difficult both of them are realized 
simultaneously, then first seen, then the highest benefit aspect of both, that is what is done. Although it must eliminate the benefit of one of them which is lower. Likewise, if there are two damage (mafsadah) meet, if it is difficult to eliminate both together, it must be reviewed, where the level of damage is the highest impact, that is what must be eliminated, even though it is forced to do other damage which has the lowest impact. "[8]

The Fourth Rule,

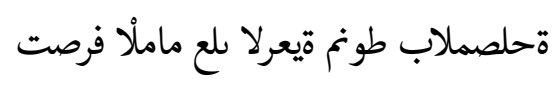

"The policy of a leader towards his people must be based on benefit"

This rule comes from the fatwa of Imam Asy-Shafi'i:

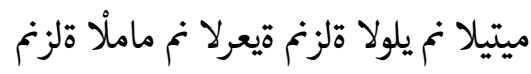

"The position of priests towards the people is like the position of guardian towards orphans".

[9] The actions and policies pursued by leaders or rulers must be in line with the public interest (maslahah mursalah) not only for certain groups or for themselves. The rulers are protectors and bearers of the people's misery. Including the authorities are those who are appointed directly by the authorities to take care of the interests of the peoples. So in this case, their position is as na'ib al-Imam (representative of the ruler).

\section{Previous Studies}

Research on the Financial Management of the agency B adan Haji (BPKH) on Ministry Religion still very minimal, however there is some research that can be used as a reference. Septiana (2015) examines the Construction of the Hajj Financial Management Model in Islamic banks in Indonesia. The methodology used in this research is qualitative and quantitative methods. According to the results of this study it can be concluded that the contract between Hajj Pilgrimage and BPKH can be do with contract wadi'ah yad dhamanah, with way this then Hajj pilgrims get economic benefits or financial benefits from managing Hajj finances so that could subsidize Cost Organizer Worship Hajj (BPIH) for the pilgrims, in addition to the management of Hajj finances (investment in Hajj funds) can be carried out by placing on the I party funds of Sharia banks as equity participation in the musyaraka mutanaqisha contract.

Alfianti (2016) examined the Overview of Islamic Wealth Management in Hajj Fund Management by the Hajj Financial Management Agency (BPKH) Based on maqashid 
sharia, using a qualitative methodology using the SAST (Strategic Assumption Surfacing and Testing ) approach. The results of his research show that in order for the management system of the Hajj fund by BPKH to be in accordance with Islamic Wealth Management, the factors that influence it are the factor of contract, stakeholder regulation factors, transparency factors and coordination factors among policy makers.

The Haura (2012) conducts research on the management of Hajj funds in the Indonesian Hajj Fund Sukuk (SDHI). This study uses a qualitative descriptive research method to determine the advantages and disadvantages of SDHI. Furthermore, this study also uses descriptive quantitative methods to determine the management of Hajj on SDHI as seen from the management of the state budget. The results obtained from this study are that of placement fund pilgrimage on SDHI profitable for Ministry Religion because it is free of default risk while from the Ministry of Finance side will add new investors in managing the budget country.

Furthermore, research in Malaysia was also carried out by Habibah Yahaya, et al (2016) and Suhaimi bin Haji Ishak (2011). Yahaya conducted research under the title paper, Tabung Haji Malaysia as a World Role Model of Islamic Management Institutions. His research shows that, the Malaysian Tube Haji Institute is the first model and becomes an icon of Islamic financial institutions in the world Muslim community that is systematic and very good at managing Hajj finances with a savings and investment system based on Islamic Shari'a and making tawhid to Allah SWT. as the main principle. The presence of LTH in the domestic and international markets has proven to develop in several investment sectors, such as sharia finance, property development, construction, information technology, oil and gas, hotels and plantations.

While Isaac made research with the title, Tabung Haji as an Is/amic Financial Institution for Sustainable Economic Development. This study uses a qualitative descriptive research method. The results concluded in this study are that the Hajj tube model in Islamic financial institutions can be used as an alternative for economic development.

The research was also conducted by Dr. Muhammad Abdul Mannan (1996) with the title paper, Is/amic socioeconomic Institutions and mobilization Of resources with special Reference Management of Malaysia. Results from this study is the hajj affairs has an important role to promote and sustain economic cooperation among Islamic countries, especially in the field of trade and joint venture projects. Besides that, he also seen as one of the most powerful sectors in the monetary sector of Muslim countries for the purpose of mobilizing domestic savings and investments in accordance with sharia as demonstrated by the successful experience of Malaysian Hajj Tubes Management. According to him, there is no reason why the experience of Tabung Haji cannot be 
replicated in other Muslim countries. Efforts must be made to disseminate the successful experience of Tabung Haji among Islamic countries.

\section{Conceptual Framework}

The purpose of this study is to find out the management system of Hajj funds by BPKH in accordance with the aspects of Islamic muamalah covenants and legal aspects of the law that are used as guidelines, as well as comprehensive requirements in sharia in investing the Hajj funds. For this reason, this study will analyze the legal aspects of the law which are used as guidelines in the management of Hajj funds by BPKH, namely Law No. 34 of 2014 concerning Management of Financial Hajj, Presidential Regulation No. 110 of 2017 concerning BPKH, Government Regulation No. 05 of 2018 concerning Management of Financial Hajj, and Forum ljtima Ulama IV which took place at the Cipasung Islamic Boarding School, Tasikmalaya Regency, West Java, on June 29, 2012 to July 2, 2012 concerning BPIH Deposit Fund Ownership Status and Utilization of Government Hajj Funds, as well as the latest fatwa MUI DSN No.122 2018 concerning Management of BPIH and Special BPIH Deposit Funds Based on Sharia Principles. From the above explanation, the author's Conceptual Research Framework is made as follows:

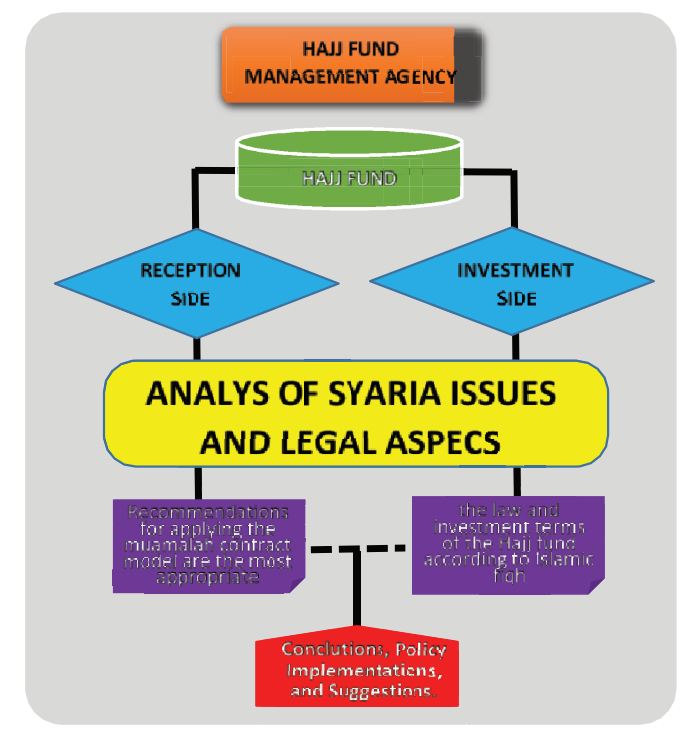

Figure 2: Conceptual Framework. 


\section{Method of Research}

This research uses descriptive qualitative methodology. Qualitative methods in this research are carried out by a process of discussion and literature study in order to obtain information from primary and secondary sources.

a. Primary sources, are the results of interviews and direct observations regarding the application of muamalah in financial management of Hajj by BPKH. Primary data is obtained by using questionnaire research materials provided to the respondents consisting of a board of experts in Islamic economics, college academics, and members of the MUI DPS and DSN.

b. Secondary sources, which are other reference materials that contain information about the management of Hajj finances, are taken from the 2018-2022 BPKH Strategic Plan report, Ministry of Religion Reports, books, muamalah figh books, classical and contemporary, scientific papers, journals, magazines, and others. other.

\subsection{Data analysis}

Data analysis was carried out using the method of documentation and interviews. This documentation method is carried out to trace the data sources contained in the document, in the form of financial reports, journals, research, and documents from various classical and contemporary figh books, and the Fatwa of the National Sharia Council of the Indonesian Scholars Council. The method of interviewing was conducted on respondents by having one of the following criteria:

1. Served as a member of the DSN-MUI

2. Served as DPS in Islamic Financial Institutions

3. College lecturers or representatives,

4. Islamic Economics Expert Board / Association of Islamic Economic Experts Purposive representative samples are used to support the interview method for reasons of competence of each resource person who is willing and able to provide accurate information for this study.

The fatwa of the DSN-MUI read in this study is a fatwa concerning muamalah relating to Wadi'ah (Fatwa No.02 / DSN-MUI / IV / 2000) , mudharaba (Fatwa No.07 / DSN-MUI / IV / 2000), musyaraka (Fatwa No. 08 / DSN-MUI / IV / 2000), ijarah (Fatwa No.09 / DSNMUI / IV / 2000), ljarah Maushufah Fid Dzimmah (Fatwa No.101 / DSN-MUI / X / 2016) , Wakalah bil Ujrah (No.113 / DSN-MUI / IX / 2017 Fatwa), investment implementation guidelines for sharia mutual funds, sukuk, financing of hajj arrangements, and the latest 
Fatwa DSN MUI No.122 2018 concerning BPIH Fund Management and Special BPIH Based on Sharia Principles.

Because this research is a library research supported by information from competent parties in their field, the analysis begins with the method of analyzing the texts contained in the books of fiqh muamalah as the views of the 'fukaha' (philosophical) scholars. Then synchronizing philosophical views with the application of muamalah contract that matches the facts and reality that exist in $\mathrm{BPKH}$, so that a synthesis gap can be found by confronting the philosophical (ideal) side with the reality side (actually) adopted by BPKH.

\section{Discussion and Research Results}

\subsection{The muamalah contract is used by the BPKH}

The management of the Hajj fund by the BPKH for its investment interests is closely related to the sighat Contracts between prospective pilgrims who are legal owners of the Hajj funds with the government which was previously represented by the Ministry of Religion, as the party that administers the Hajj pilgrimage to the $\mathrm{CJH}$. Sighat contract is something that is based on two parties who have faith that shows what is in their hearts about the occurrence of a contract. Sighat Contracts can be done by means of oral, written, or gestures that give a clear understanding of the existence of qabul (handover), and can be in the form of actions that have become habits in consent and qabul. [10]

However, if you look at the existing PKH Law No.34 of 2014, it can be seen that this Act only addresses the affairs of the Hajj Financial Management Agency that manages Hajj Finances, which includes funds deposited through deposits of prospective pilgrims. Again, the construction of the law and its legal relationship are safekeeping of money. If you look at the contents of this clause, it seems that the muamalah contract implied in the management of this fund is the Wadi'ah contract (deposit of funds), because muamalah that accommodate and explain someone's deposit to another person, are the wadi'ah contract.

This refers to Article 7 paragraph (1) of the PKH Law which states that the hajj deposit fund is "legal status is entrusted" as referred to by the funds deposited by the Hajj Pilgrims. This means that negatively the deposit funds are not Government funds and not the funds belonging to the BPKH. There are no diction, let alone the norms and 
classifications in the PKH Law which mention the existence of authorization (wakalah contract) from the fund owner to the recipient of the power to manage.

Based on the discussion, in Article 1 number 4 of the PKH Law No. 34 of 2014, it is only mentioned that the BPKH is an institution that carries out financial management of Hajj. In this provision, BPKH is referred to as the proxy for funds deposited by Hajj Pilgrims to be managed by themselves, which by law are deemed to have received power from the depositors of prospective pilgrims who deposit BPIH and / or Special $\mathrm{BPIH}$. This is also made clear by the explanation of Article 6 paragraph (2), that, BPIH and / or Special BPIH deposits as referred to in paragraph (1) are paid to accounts in the name of BPKH in their position as legitimate representatives of Jemaah Haji at Cash Hajj through BPS BPIH.

Provisions regarding the filling and signing of the Wakalah Agreement between prospective pilgrims and the government (represented by the Ministry of Religion) only later became clear, after seeing the practice that occurred when the prospective pilgrims deposited their hajj funds into Islamic banking. There is a BPIH deposit form sheet that regulates the power of attorney agreement (wakalah contract) between the pilgrims and the ministry of religion. All of these provisions have been arranged and agreed upon in the Cooperation Agreement between the Directorate General of Hajj and Umrah, the Ministry of Religion, with the BPIH Deposit Recipient Bank regarding the receipt and payment of BPIH. [11]

In the contract form for the initial BPIH deposit, the prospective pilgrims as Muwakkil authorize the Ministry of Religion as the Deputy, to receive and manage the initial BPIH deposit funds that have been deposited through the Sharia Commercial Bank or Sharia Business Unit as the designated BPIH Deposit Recipient Bank (BPS) by BPKH, in accordance with the provisions of Law No. 34 of 2014 article 1 paragraph (7) and article 6 paragraph (2) as previously explained. The application of the wakalah contract is also regulated when the hajj finance is managed by the BPKH. Law Number 34 of 2014 concerning Financial Management of Hajj and PP. No. 5 of 2018 concerning the implementation of the Act, stipulates that the BPKH as a Representative will receive a mandate from prospective pilgrims as Muwakkil to receive and manage BPIH deposit funds. From this it becomes clear, that the underlying contract between the prospective pilgrims and the BPKH is the Wakalah Agreement.

The provisions of the muamalah agreement on the management of the Hajj fund by the government became even clearer after the issuance of the MUI DSN fatwa NO. 122 / DSN-MUI / II / 2018 Regarding Management of BPIH and Special BPIH Funds Based on Sharia Principles. It was stated in the fatwa, that muamalah contract that underlies the 
management of BPIH and BPIH Special funds is the Wakalah Bil Ujrah Agreement. So that the BPKH through the wakalah agreement that has been signed by each $\mathrm{CJH}$, has the authority to place hajj finance on various investments. Where the value of benefits (yields) on the results of the financial management of the pilgrimage is intended for the greatest interest of the pilgrims. This refers to the laws and regulations related to the management of Hajj funds. Law Number 34 of 2014 concerning Financial Management of Hajj which stipulates that BPKH as a Representative will receive full mandate from $\mathrm{CJH}$ as Muwakkil to receive and manage funds for BPIH deposits.

\section{Some Models for the Implementation of the Muamalah Contracts on the Management of Hajj Funds by BPKH}

As in general in the business world in financial institutions in managing public funds, including in BPKH institutions, there are two sides to business activities, namely the side of receiving funds, and the side of utilization of funds. From the results of a summary interview with respondents who are composed of expert experts in their fields, it can be concluded, that on the side of receiving hajj funds, BPKH can apply several models of muamalah that are varied in their application. There are four models of muamalah contract that can be applied. Namely (1) Contract of Wadi'ah Yad Dhamanah, (2) Mudharabah Agreement Muthlaqa, (3) Wakalah contract bil Ujrah, and (4) Contract of ljarah Maushufah Fid Dzimmah (IMFD).

While in terms of utilization of the hajj funds, BPKH can also apply several models of muamalah in its application. At least from the results of interviews with respondents it was concluded that there were also four. Namely: (1) Mudharaba agreement, which is a profit-sharing contract with full capital from the BPKH then the profit ratio is mutually agreed. (2) Musyaraka contract, which is a capital participation contract from BPKH for example sharia banking or other sharia-compliant companies, where the profit ratio between the two parties is agreed at the beginning. (3) Bai 'contract (Buy and sell). For example, Bai' Murabaha, Istishna' and Salam), and (4) ljarah Agreement. These muamalah contract models are applied in order to fit the legal aspects and fulfill sharia principles. If illustrated in the diagram frame, it looks like the following picture:

From the above model, we can know that many alternative choices of muamalah contract can be applied in the management of Hajj funds by BPKH. However, among these, of course there is a contract model that is most appropriate to be applied in accordance with the reality that occurs. But beforehand, we will discuss one by one the 


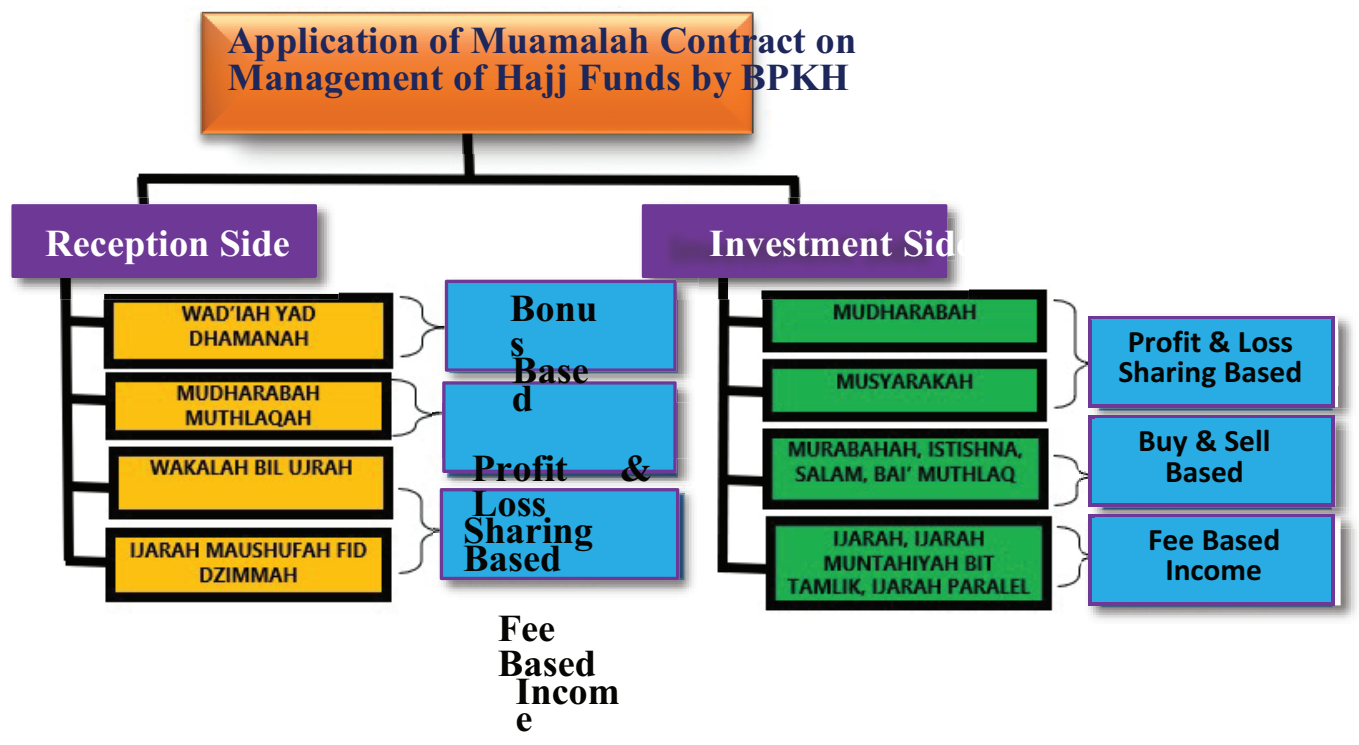

Figure 3: Application of Several Models of Muamalah Agreement on Management of Hajj Funds by BPKH.

models for implementing the muamalah agreement above in the management of the Hajj fund by BPKH.

After analyzing various legal aspects of the Law along with other regulations regarding the management of the Hajj fund by BPKH, it can be concluded, that the type of muamalah contract used between Jemaah Hajj and BPKH is the Wakalah al-'Ammah contract, which is a general contract of Jemaah Hajj to BPKH to manage pilgrimage funds belonging to the congregation to any sector that is considered maslahah for the benefit of the congregation. With Wakalah al-Ammah this, the BPKH has extensive authority in managing the hajj funds collected in sectors that are deemed to produce good and attractive returns. The pilgrims also did not burden the BPKH in specifically determining the management of their hajj funds to certain sectors. With the use of this wakalah contract, BPKH can carry out various types of investments in the form of profit-based, buying and selling, or leasing.

Therefore, if you look at the BPKH policy framework in the management of Hajj fund investments depicted in the 2018-2022 BPKH and RKAT Strategic Plans that have been approved by the Supervisory Board and Members of the Indonesian House of Representatives Commission VIII, the implementation model of muamalah agreement for the utilization of Hajj financial investment activities is in accordance with the Plan Existing strategies can be described as follows:

From table I the above in mind, that the activities of the investment made BPKH not be separated from the three contract tijari (commercial) below:

First, covenants profit sharing based, namely contract Mudaraba and Musharaka. 
TABLE 1: Classification of the Model of Implementation of the Muamalah Agreement on Placement and Financial Investment of Hajj by BPKH.

\begin{tabular}{|c|c|c|c|c|}
\hline No. & Instrument type & Contract Base & $\begin{array}{l}\text { Name of } \\
\text { Covenant }\end{array}$ & Covenant Guidelines \\
\hline & $\begin{array}{l}\text { Hajj Financial } \\
\text { Placement }\end{array}$ & & & \\
\hline 1 & $\begin{array}{l}\text { Placement - } \\
\text { Sharia Business } \\
\text { Bank Deposits }\end{array}$ & Profit sharing & Mudharaba & $\begin{array}{l}\text { Fatwa No.03 / DSN-MUI / IV / } 2000 \\
\text { concerning Deposits } \\
\text { In accordance with Fatwa No.7 / } \\
\text { DSN-MUI / IV / } 2000 \text { concerning } \\
\text { Mudharaba. }\end{array}$ \\
\hline 2 & $\begin{array}{l}\text { Placement - } \\
\text { Current Account }\end{array}$ & Profit sharing & Mudharaba & $\begin{array}{l}\text { Fatwa No.01 / DSN-MUI / IV / } 2000 \\
\text { concerning Current Accounts. }\end{array}$ \\
\hline \multirow[t]{2}{*}{3} & $\begin{array}{l}\text { Placement - } \\
\text { Savings }\end{array}$ & Profit sharing & Mudharaba & $\begin{array}{l}\text { As per Fatwa No.0 } 2 \text { / DSN-MUI / IV } \\
\text { / } 2000 \text { concerning Savings }\end{array}$ \\
\hline & $\begin{array}{l}\text { Hajj Financial } \\
\text { Investment }\end{array}$ & & & \\
\hline 4 & $\begin{array}{l}\text { Investment - } \\
\text { Shares }\end{array}$ & $\begin{array}{l}\text { Profit Sharing } \\
\text { (Participation } \\
\text { Capital) }\end{array}$ & Musyaraka & $\begin{array}{l}\text { According to Fatwa No. } 08 \text { / DSN- } \\
\text { MUI / IV / } 2000 \text { concerning } \\
\text { Musyaraka }\end{array}$ \\
\hline 5 & $\begin{array}{l}\text { Investment - State } \\
\text { Sharia Securities } \\
\text { (SBSN) }\end{array}$ & Ujrah (Fee ) & ljarah & $\begin{array}{l}\text { - Fatwa No.69 / DSN-MUI / V I / } 200 \\
8 \text { About SBSN. } \\
\text { - Fatwa No.72 / DSN-MUI / VI / } 2008 \\
\text { concerning SBSN ljarah Sale and } \\
\text { Lease Back. } \\
\text { - Fatwa No.20 / DSN-MUI / IV / } 2001 \\
\text { concerning Sharia Mutual Funds. } \\
\text { - Fatwa No.80 / DSN-MUI / III / } 2011 \\
\text { concerning Application of Sharia } \\
\text { Principles in Securities Trading. } \\
\text { - Fatwa No. } 95 \text { / DSN-MUI / VI / } 2014 \\
\text { concerning SBSN Wakalah. }\end{array}$ \\
\hline 6 & $\begin{array}{l}\text { Investment - } \\
\text { Corporate Sukuk }\end{array}$ & Ujrah (Fee ) & ljarah & $\begin{array}{l}\text { - Fatwa No.09 / DSN-MUI / IV / } 2000 \\
\text { concerning ljarah. } \\
\text { - Furthermore, it is the same as the } \\
\text { DSN Fatwa concerning the SBSN } \\
\text { above. }\end{array}$ \\
\hline 7 & Investment - Gold & $\begin{array}{l}\text { Buy and Sell } \\
\text { (Margin) }\end{array}$ & $\begin{array}{l}\text { Bai' Murabaha, } \\
\text { Bai' Bitsamanin } \\
\text { Ajil, Bai 'Salam, } \\
\text { Istishna'. }\end{array}$ & $\begin{array}{l}\text { - Fatwa No. } 4 \text { / DSN-MUI / IV / } 2000 \\
\text { About Murabahah } \\
\text { - No. Fatwa } 77 \text { / DSNMUI / V / } 2010 \\
\text { concerning Gold Murabahah. } \\
\text { - Fatwa No. } 26 \text { / DSN-MUI / III / } 2002 \\
\text { concerning Rahn Emas }\end{array}$ \\
\hline 8 & $\begin{array}{l}\text { Investment - } \\
\text { Direct } \\
\text { Participation }\end{array}$ & $\begin{array}{l}\text { Buy and Sell } \\
\text { (Margin) }\end{array}$ & $\begin{array}{l}\text { Bai' Murabaha, } \\
\text { Bai' Bitsamanin } \\
\text { Ajil, Bai' Salam, } \\
\text { Istishna'. }\end{array}$ & $\begin{array}{l}\text { Fatwa No.0 } 4 \text { / DSN-MUI / IV / } 2000 \\
\text { concerning Murabahah }\end{array}$ \\
\hline 9 & Other investments & Profit sharing & $\begin{array}{l}\text { Mudharaba } \\
\text { Muqayyada }\end{array}$ & $\begin{array}{l}\text { In accordance with Fatwa No.7 / } \\
\text { DSN-MUI / IV / } 2000 \text { concerning } \\
\text { Mudharabah. }\end{array}$ \\
\hline
\end{tabular}


Mudharabah is a partnership agreement between two or more people, where one party provides $100 \%$ investment capital, while the other party has the skill (expertise) in managing the capital, with a profit sharing ratio agreed upon in advance between the two. While the Musyaraka contract is a partnership agreement between two or more parties, both of which include cooperation capital, with a profit sharing ratio agreed at the beginning of the contract. With Mudharaba and Musyaraka contract models This can be used by BPKH for its investment activities in the fund placement sector in the form of Mudharabah Deposits and Demand Deposits in Sharia Banking, Shares, Equity Participation, and Sharia Mutual Funds. Where these products are profit-based based on Mudharabah contract schemes such as Deposits and Demand Deposits in Islamic banking, and Musyaraka contract schemes such as equity participation products, and sharia mutual funds. In addition, the products of placement and investment in Deposits, Current Accounts and Mutual Funds are in accordance with MUI DSN fatwas No. 03 / DSN-MUI / IV / 2000 concerning Deposits, Fatwa No.7 / DSN-MUI / IV / 2000 concerning Mudharaba, Fatwa No. 08 / DSN-MUI / IV / 2000 concerning Musyaraka, fatwa No. 01 / DSN-MUI / IV / 2000 concerning Current Account, and Fatwa No.20 / DSN-MUI / IV / 2001 concerning Sharia Mutual Funds.

In fact, according to Nurul Izzati (2015) to maximize the benefits gained in the placement of BPKH in Islamic banking, BPKH in managing Hajj finance (investment in Hajj funds) can be done by placing Islamic banks on Islamic party I funds with Musyaraka Mutanaqisha. The distribution of profits between BPKH and Islamic Banks if using the Musyaraka Mutanaqisha agreement in the management of Hajj finances, is fairer, because the happiness is based on the composition of the capital of each partner. The greater the capital included, the greater the profits obtained. Vice versa.

As explained above, that the Musyaraka Mutanaqisha Agreement is a collaboration between two or more parties in the ownership of an item or business in which one party takes over the share of the other party so that the person becomes the sole owner of the said goods or business. In the context of ownership of goods, the intended goods are goods that can be leased or traded, for which the results of rental income or profits are shared with the parties. In the context of business ownership, the parties' equity participation can be in the form of a new business or a business that is already running. The related business profits and losses are shared with the parties. This is in accordance with Fatwa No. 73 / DSN-MUI / XI / 2008 About Musyaraka Mutanaqisha.

Second, covenants fee based (Fee based incomes), namely the contract of ljarah pure, ljarah Muntahiya Bittamlik (IMBT), or ljarah Parallel. ljarah contract is a contract of cooperation between two or more parties, with one party providing services, and the 
other party purchasing the service with ujrah agreed upon. Where ujrah paid is fixed income, it can be known at the beginning clearly. While the ljarah Muntahiya Bittamlik contract is a contract for leasing goods, which at the end of the rental period, there is a transfer of ownership of goods from the owner of the goods to the tenants of goods. Transfer of ownership takes place at the end of the contract, with the process of buying and selling with an agreed sale price, or with a grant contract (gift). The Parallel ljarah contract is a leasing contract to continue, where someone rents an item, then the item is rented again to another person.

With this model can be used by BPKH for its investment activities in the financial sector such as Corporate Sukuk, Sharia Sukuk, SDHI, National Sharia Securities, Accommodation Rentals in Saudi Arabia, Hotels, Malls, shopping stores, or Airline Rentals Flight. Where all of these instruments use service-based, fees, ijarah contract. This is in accordance with the MUI DSN fatwa No. Fatwa No.09 / DSN-MUI / IV / 2000 concerning ljarah, Fatwa No.69 / DSN-MUI / VI / 2008 concerning SBSN, Fatwa No.72 / DSN-MUI / VI / 2008 concerning SBSN ljarah Sale and Lease Back, Fatwa No.20 / DSN-MUI / IV / 2001 concerning Sharia Mutual Funds, and No. Fatwa. 80 / DSN-MUI / III / 2011 concerning Application of Sharia Principles in Securities Trading.

If viewed from the Strategic Plan BPKH years 2018 - 2022 and RKAT 2018, which was approved by the House of Representatives in March 2018 ago, indeed the future, the board BPKH will focus on developing investment Hajj fund her on the financial sector, such as Islamic banking, sukuk Islamic and the investment will gradually expand into the infrastructure development sector in Saudi Arabia, after in - depth studies have been conducted on the feasibility of investing in the KSA and have established cooperative relations with the local government. The respondents in this study also admitted, for example Dr. Mohammad Mahbubi Ali and Ir. Agustianto Mingka, that the current business sector that produces a fairly good and safe return or minimal risk, is investment in domestic infrastructure guaranteed by the Government. Because Hajj funds must be managed with the principle of prudence and produce. While investment in infrastructure development in the country has fulfilled this principle.

Third, buying and selling, including Murabahah, Salam, Istishna, and Bai' Muthlaq. Bai' Murabahah is a sale and purchase contract by mentioning the cost of goods, then mentioning the profit margin desired by the seller. While the contract Bai 'Salam is a contract of sale and purchase which is an order (order) by paying a down payment at the beginning of $100 \%$, then the goods will be delivered later. For example, ordering agricultural, plantation, agro-business products, such as rice, corn, soybeans, etc., with advances paid at the beginning of $100 \%$, then the goods are given later at harvest. The 
contract of Bai 'Istishna' is almost the same as the definition Bai 'Salam. The difference is that there is the ordered product and the term for the down payment. Istishna's products are more industrial and construction in nature. For example, the message is to make chairs, tables, cabinets, or order to make toll roads, buildings, hotels, housing, and others. While advances in the Istishna' contract may be paid at the beginning, in the middle, even at the end of the installment system. Then what is meant by Bai' Muthlaq (ordinary buying and selling) is buying and selling without any information on the cost of goods, and there can be bargaining of goods between the seller and the buyer. So the profit is only known by the seller.

With this model of buying and selling, according to Mahbubi Ali and Agustianto Mingka, can be used by BPKH for its investment activities in sectors that produce fixed income, such as the construction of infrastructure, toll roads, procurement of food and beverages for pilgrims, other halal food products, as well as the procurement of Hajj equipment, such as the procurement of Ihram cloth, uniforms, turban, luggage bags, airline purchases, or investment in purchasing gold, property, and other direct investments. Because this is also in accordance with the DSN MUI fatwa No. 04 / DSNMUI / IV / 2000 concerning Murabahah, Fatwa No. 05 / DSN-MUI / IV / 2000 concerning Salam, and Fatwa No. 06 / DSN-MUI / IV / 2000 concerning Istishna'.

\subsection{Determination of contracts is the most appropriate model for the management of Hajj Financial funds by BPKH}

Seeing from the practice in the field in applying the deposit of Hajj funds from the congregation to the BPKH, then based on the interviews of several resource persons and references to the figh books muamalah, the most appropriate use of muamalah contract in managing (receiving) Hajj funds by BPKH is the ljarah contract Maushufah Fid Dzimmah (IMFD).

To test and determine which contract is the most appropriate and assess the substance of the contract which is most suitable to be applied between prospective pilgrims and the Ministry of Religion, the following will be presented in several clusters of : [12]

a) If the price is paid in advance and the goods are paid in advance as well, then this contract is called a sale and purchase contract (al-Bai 'al-Muthlaq).

b) If the price is paid in advance and the goods or benefits of the goods are submitted to the tempo at a later date, the agreement is more appropriate in this form is a contract greeting, istishna, ljarah and the like. 
c) If the price is paid due and the item is paid in advance, this contract is called Bai' taqsit and Bai' murabaha and the like.

d) If the price is paid by the tempo and the item is paid due, then this is called Bai' dain bi Ad-Dain or includes bai' al-Kali 'bil Kali' (buying and selling debt with debt) which is prohibited in the Prophet's hadith.

To clarify again the testing of a contract, some questions will be raised as below to determine the accuracy of a contract:

1. What is the object of traded goods in payment practices BPIH to Kemenag RI happened today? In the form of units of goods per step or in the form of hajj departure services?

2. Is the object of the benefits purchased pilgrims can already be accepted at the start time of the contract, or transaction objects that will be submitted at a later date?

3. Is the payment of the pilgrimage to the Ministry of Religion carried out at the beginning of the contract, or later?

4. Is there any clarity about the price of payments from the Indonesian Ministry of Religion to the services of hajj departure?

From the questions above, we can answer them according to the current practice and reality related to BPIH deposits of pilgrims to the Ministry of Religion, that:

1. The object transacted between the pilgrims and the Ministry of Religion (BPKH) is in the form of a haj pilgrimage package service that covers everything from aviation services, lodging services, health, security, to services for carrying out hajj services.

2. The hajj departure package service cannot be received by the congregation at the beginning of the contract, but later on, when the hajj quota has arrived.

3. BPIH payments are paid by the congregation at the beginning of the contract at the time of the transaction.

4. The price of BPIH is clear from the Ministry of Religion, through official announcements that are socialized in each Ministry of Religion office. Where the initial BPIH deposit that must be paid by each congregation is Rp25 million through a Deposit Recipient Bank that has worked with the Ministry of Religion.

From the explanation of these answers and looking at the cluster of types of transactions mentioned above, we will find several keywords in the form, the contract object in the form of services, payment at the beginning of the contract, but the services cannot be handed over at the beginning. Therefore, the type of contract that is most appropriate is applied in the process of registering the Hajj between the pilgrims and the Ministry 
of Religion, namely: ljarah Maushufah fi Dzimmah Contract. Among the rules of the ljarah contract Maushufah fi dzimmah which are related to this discussion are:

a) The scholars agreed that this kind of ljarah contract is allowed in Islam, according to the hadith of the Messenger of Allah:

"Whoever hires a workers' labor, then it should notify the fee nominal"

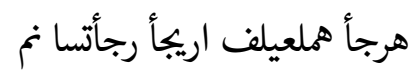

b) A person who promises to rent goods or services, he may be asked to submit a Hamish jiddiyah (finished mark) with a face argument (secondary needs) and the mashlahah principle to ensure the seriousness of musta'jir. Because wa'ad mulzim (binding promise) gives birth to consequences such as property sanctions, and others.

c) Contracts ljarah maushufah fi dzimmah allowed as well as contract greeting, because it does not give rise to disputes. According to Syafi'iyah and Hanabilah no wages are required in advance.

The IFMD agreement has many advantages over other muamalah in the application of hajj funds received by BPKH. If we look lengthy explanation in earlier about the application Contracts- Contracts muamalah start of the contract Wadi'ah Yad Dhamanah, Wakalah Bil Ujrah, Mudharaba muthlaqa, and ljarah Maushufah Fid dzimma, then each contract has a character each with all the risks and the consequences. Below, the author will describe the character and consequences of each contract if it is associated with the application of the BPIH pilgrimage deposit to BPKH:

From the explanation of the table above, we can conclude, that the contract model that is appropriately applied in the case of registering BPIH deposits of pilgrims to BPKH is indeed the ljarah Maushufah Fid Dzimmah contract. Thus this can be seen from several factors:

1. Contracts Wadi'ah although it could be applied in the management of haj funds, but actually not accurate enough to be applied in the deposit BPIH to BPKH. Because, the contract of Wadi'ah as explained above is actually including the tabarru' contract which is a mandate, not a contract aimed at Mu'awadhat Tijariyyah (Commercial Business). Therefore, when given permission to treat his property, the nature of this contract is changed to yad dhamanah, in other words meaning Qardh. Obviously this is not the right contract with the reality that happens. Because, the congregation did not intend to owe the government over the funds. In addition, according to Irfan Syauqi Beik in the author's interview, he said that the character of Wadi'ah can be taken at any time (unless previously there was a binding agreement). So it becomes very unlikely, funds that have been deposited by the congregation, can be taken at any time by the congregation 
TABLE 2: Explanation of Each Contract Character and Its Consequences.

\begin{tabular}{|c|c|c|c|c|}
\hline Type of contract & $\begin{array}{l}\text { Covenant } \\
\text { character }\end{array}$ & $\begin{array}{l}\text { Hajj Fund Deposit } \\
\text { Status }\end{array}$ & $\begin{array}{l}\text { Status of Owner } \\
\text { Benefits of } \\
\text { Management }\end{array}$ & $\begin{array}{l}\text { Consequences of } \\
\text { Contract }\end{array}$ \\
\hline $\begin{array}{l}\text { Wadi'ah Yad } \\
\text { Dhamanah }\end{array}$ & $\begin{array}{l}\text { Tabarru'aat } \\
\text { (Social) and } \\
\text { Dhamanah } \\
\text { (Responsibility to } \\
\text { replace) }\end{array}$ & $\begin{array}{l}\text { Treasure Courier } \\
\text { that can be taken at } \\
\text { any time. }\end{array}$ & $\begin{array}{l}\text { Property Manager } \\
\text { (BPKH) }\end{array}$ & $\begin{array}{l}\text { must return the } \\
\text { deposits in full } \\
\text { (BPIH) whatever the } \\
\text { conditions. }\end{array}$ \\
\hline $\begin{array}{l}\text { Mudharabah } \\
\text { Muthlaqah }\end{array}$ & $\begin{array}{l}\text { Tijari } \\
\text { (Commercial) and } \\
\text { trustful. }\end{array}$ & $\begin{array}{l}\text { Mudharabah } \\
\text { Investment Assets } \\
\text { that can be taken } \\
\text { based on the agreed } \\
\text { period of time. }\end{array}$ & $\begin{array}{l}\text { Owned Together } \\
\text { between } \\
\text { Managers \& Fund } \\
\text { Owners } \\
\text { (According to } \\
\text { Ratio) }\end{array}$ & $\begin{array}{l}\text { The principal (BPIH) } \\
\text { must be returned if } \\
\text { the investment has } \\
\text { been completed. But } \\
\text { there is no obligation } \\
\text { to return it principal } \\
\text { funds if there is a } \\
\text { loss. }\end{array}$ \\
\hline Wakalah bil Ujrah & $\begin{array}{l}\text { Tabarru'aat } \\
\text { (Social) and } \\
\text { trustful. }\end{array}$ & $\begin{array}{l}\text { Treasure entrusted } \\
\text { by proxy (Muwakkal } \\
\text { Bih), can be taken if } \\
\text { the affairs of } \\
\text { Wakalah it has been } \\
\text { completed. }\end{array}$ & $\begin{array}{l}\text { Belongs to the } \\
\text { representative } \\
\text { party (Shahibul } \\
\text { Mal / hajj pilgrim) }\end{array}$ & $\begin{array}{l}\text { Muwakkal bih (BPIH) } \\
\text { Must be returned to } \\
\text { the party } \\
\text { representing if the } \\
\text { business has been } \\
\text { completed, whatever } \\
\text { happens the risk. }\end{array}$ \\
\hline $\begin{array}{l}\text { ljarah Maushufah } \\
\text { Fi Dzimmah }\end{array}$ & $\begin{array}{l}\text { Tijari } \\
\text { (Commercial) and } \\
\text { trustful. }\end{array}$ & $\begin{array}{l}\text { Ujrah for services } \\
\text { purchased and } \\
\text { cannot be taken } \\
\text { anymore, because } \\
\text { the purpose is to pay } \\
\text { for the purchase } \\
\text { price of services. }\end{array}$ & $\begin{array}{l}\text { Property Manager } \\
\text { (BPKH) }\end{array}$ & $\begin{array}{l}\text { No obligatory } \\
\text { returned BPIH to the } \\
\text { congregation from } \\
\text { the beginning of the } \\
\text { contract, because it } \\
\text { has become an ujrah } \\
\text { for the purchase of } \\
\text { the Hajj package }\end{array}$ \\
\hline
\end{tabular}

when needed. The choice of the contract of Wadi'ah in terms of managing this Hajj fund became less relevant.

2. The Wakalah bil ujrah contract is basically the same as the legal details of the Wadi'ah contract. That is both a tabarru'aat contract and not muawadhat tijariyyah. Because the purpose of this Wakalah contract is only an intermediary contract (wasilah) not a goal contract (ghayah). Therefore, he is called Tabarru' contract (social). Whereas in the case of BPIH deposit registration to the Government (BPKH), the pilgrims did not intend to really represent their BPIH funds to be managed by the BPKH. Because, if the purpose is only to represent their assets to be invested, then this can be done in addition to BPKH, for example in Banking, in the Capital Market, in mutual funds, or in other companies that are specifically working in the field of investment services. While in the case of $\mathrm{BPIH}$, the congregation indeed ordered that they deposit funds for the pilgrimage departure list. If the Government does not have priority rights for the services of hajj departure, of course they will not carry out this Wakalah bil ujrah contract. In 
addition, the Wakalah contract consequences that the entire investment belongs to Muwakkil as the owner of the funds, while ujrah to the deputy, must be explained in the initial contract with the sheer numbers (knowingly). Another disadvantage is that this Wakalah contract includes the contract of Jaizun min at-Tharafain, meaning that one party may cancel unilaterally, whenever desired, without the consent of the other party. Then of course this becomes increasingly difficult to avoid. Except if using ujrah in this representative. Cannot be canceled unilaterally. But according to the jurists, if the Wakalah contract using ujrah, actually it includes the ijarah contract. Because, the object of the transaction is service, and hence ujrah (wages) paid must also be clear at the beginning. See the statements of the fiqh scholars below:

"Wakalah contract may use iwadh (wages) and may be without iwadh. If Wakalah uses iwadh, then it includes the ijarah contract which becomes prevalent (binding on both parties). The consequence is that the ujrah must be explained, the time determined and the type of work must be known." [13]. "Ibnu Jazi said, Wakalah may use ujrah and without ujrah. If Wakalah uses ujrah, then the law is the ijarah contract law. If without the ujrah, it is an act of mercy (virtue) from the recipient of the power of attorney (Deputy). "[14] "The fourth law for Wakalah, namely the freedom of both parties to carry out the contract or stop it. That is, one party may stop the Wakalah contract. So if there is no ujrah (wages) in it. If there is a wage agreement in it, it can be said ijarah contract. If it is signed using the ijarah sentence, then it is binding. If it is signed using the Wakalah bil ujrah sentence, then the rules of fiqh rules apply, which explains, "what is considered in a transaction is the substance, not the words." [15]

3. The Mudharabah Muthlaqah contract is also not appropriate if applied in the reality of registering BPIH for pilgrims to the Ministry of Religion. Just like the details of the legal explanation above, that the pilgrims deposit their hajj funds to the Ministry of Religion not because they just want to invest. Because, the people knew, that the Ministry of Religion was not an Investment Manager Agency, and indeed there was no agreement on the Mudharabah agreement at the beginning. The congregation is pure in depositing its BPIH because there is an interest in hajj departure, where the Ministry of Religion is the only state institution that has priority rights in regulating it. In addition, if BPIH deposits the congregation from Mudharabah, the risk is very high. It could be, when the investment made by the BPKH for example fails, then the hajj fund does not return, and it has the potential to fail the haj pilgrimage departure plan. The consequences of the Mudharabah contract also require the return of the principal of Shahibul Mal's assets if 
the investment is completed. Whereas in reality, there is no BPIH deposit returned to the congregation even though the investment period has been completed.

4. The only contract that is most appropriate and appropriate to use in the case of BPIH deposits between pilgrims and BPKH is the Contract of ljarah Maushufah Fid Dzimmah. Where the object of the contract is a service, the type of contract is mu'awadhah tijariyyah (Commercial Contract), the purpose of the contract is also clear, is to buy the services of the pilgrimage package to the government, with ujrah being paid at the beginning, and services will be used later. The consequences of this ijarah contract are binding on both parties. That is, one party cannot cancel the contract without the permission of one of them. Another advantage, is that in the IMFD contract, the BPKH also does not need to return the existing BPIH deposit funds, because Sharia law is already owned by the Government. Instead, the Government is obliged to provide pilgrimage departure services to pilgrims when their quota arrives later. Moreover, the fatwa regarding the IMFD agreement has also been issued for a long time since 2016. This means that the Government can refer to the MUI DSN Fatwa on the IMFD as a guideline for managing the Hajj fund for BPKH.

\subsection{Laws and Conditions for Investing in Hajj Funds in the Islamic Jurisprudence Perspective}

In accordance with the results of the forum for the Association of Islamic Scholars (Forum Ijtima' Ulama) decision that was held in Cipasung - Tasikmalaya, on July 2, 2012 concerning the law utilizing the Hajj fund by the Government, also supported by the MUI's DSN Fatwa No. 122 / DSN-MUI / II / 2018 Concerning BPIH and Special BPIH Fund Management Based on Sharia Principles, it is stated that the law to invest in Hajj funds for the government is permissible, both in sectors that are directly or indirectly related to the interests of pilgrims, with conditions: invested in halal sectors in sharia, and not placed in sectors whose halal status is still doubtful or prohibited by Islamic law. Such as being channeled to Conventional Banking, Liquor Factories, Conventional Insurance, and so on from industries that do not meet sharia principles.

Referring to the provisions of Law No. 34 of 2014 concerning Management of Financial Hajj and the results of Ijtima Ulama IV Commission B-2 of the 2012, Scholars Council of the Indonesian Ulama Fatwa Commission, management of Hajj funds for investment needs in productive sectors such as infrastructure development, plantations, agro business, marine, and other real sectors, can still be possible. The condition is that 
investment in these sectors has a low level of risk, has a benefit value for pilgrims, and its management is based on sharia principles.

The next debate is about the benefits for the benefit of the pilgrims.

From the results of interviews with respondents consisting of expert experts, provide an explanation that the intended benefit needs to be prioritized always with the interests of pilgrims. This means that if the Hajj funds are used for infrastructure development, for example, the infrastructure is intended for the smooth and comfortable hajj pilgrims, such as the construction of Hajj lodging dormitories around the Grand Mosque or the construction of hospitals for health facilities for pilgrims. According to $\mathrm{KH}$. Cholil Nafis, as an expert resource person, for example, in an interview conducted by the author, stated that the intended benefit was in a broad sense, namely for Muslim communities in general, not obligatory to be related to the interests of pilgrims, but still prioritized and would be better for the benefit of the pilgrims. Therefore, laws and regulations are needed which strictly regulate the limits of the benefit of the people.

From a number of sharia foundations which consist of verses A -Quran and the Hadith of the Prophet above, we can conclude that in Islam it does not basically matter about doing a business and acting in any sector, as long as there are no texts from the Koran and Hadith that forbids it and forbids it. As for if there is a text that forbids it, it should not or is not permissible to invest in it. Something which is prohibited in a business that if she was carrying a case of vanity (for stealing or taking other people's rights are dzulm), maysir (gambling/speculative), riba (interest / usury), gharar (vagueness object of the contract), tadlis (fraud) and ihtikar (stockpiling).

If we associate with the investment requirements of this Hajj fund, according to interviewees Mohammad Mahbubi Ali, the closest methodology approach to Qiyas (Legal Analogy) is if he is analogous to managing the assets of orphans by a guardian who gets the trust to guard them. Where requirements are allowed to invest the funds of funds belonging to orphans that according to Imam al-Mawardi in his book, al-Hawi Fi Fiqh as-Shafi, is a staple of managed assets (invested) should not be reduced, should be maintained and there must be a guarantee of security and generate profits [16]. From several al-Quran and Hadith arguments and the results of interviews with several expert resource persons in this study, it can be concluded, that the BPKH can invest the Hajj funds belonging to the pilgrims, the law is permissible and legally both legally the Law, and in Islamic fiqh law, with several conditions the following:

The first requirement, fulfilling the legal aspects of positive and legal sharia laws. Legal aspects of positive law, the meaning must not conflict with Law number 34 of 2014 concerning financial management of Hajj, Government Regulation No.5 of 2018 
concerning Implementation of the Law on Management of Financial Hajj and Presidential Regulation No.110 of 2017 concerning BPKH. Whereas the legal aspect of sharia means that the Hajj financial funds must be invested in a sector that is lawful and in accordance with Islamic sharia, meaning that it is free from the prohibited elements above, such as maysir, gharar, riba tadlis, ihtikar, and bathil (evil). Then it is not permissible to invest it in the deposit of the conventional bank in return for usury (interest) or in business sectors that have speculative systems (Maysir), obscurity or obscurity of objects (gharar), fraudulent businesses (tadlis), for example investments in foreign exchange that are not cash, short-term buying and selling indices (short selling), MLM that is charged with money games, and others.

Terms Secondly, as a condition clicking investment right zakat and the orphan's property, the urgent need of a right to these funds has been met, new funds may invest these people. That means, if analogous to this condition, it is permissible to invest this hajj fund if the urgent needs of the pilgrims have been fulfilled properly. Both concerning the facilities and infrastructure of the pilgrimage for the smooth implementation of the pilgrimage of pilgrims or related to service during the implementation of the Hajj. If this is fulfilled, it is considered right to invest Hajj funds in other sectors that are not related to the Hajj business. But if not, it is not allowed to invest in any projects that are not related to the matter of Hajj. So, in this case the BPKH must take priority measures; al-Aula fa al-Aula, or the bigger utility (maslaha). In accordance with the jurisprudence rules according to the fiqh rules "When two things happen, they must intersect with each other, so the most important ones are prioritized ". [17]

Terms Third, Hajj funds should not be placed in any investment project except after studying the business feasibility (Physical Study) of the project properly, and there is a great belief that the targeted sector will benefit. Because, the purpose of investment is to get a profit. Therefore, all risks must be truly identified, measured, monitored and then controlled (mitigated) so as not to harm the principal assets of the Hajj fund. In an interview conducted with Dr. Mohammad Mahbubi Ali and Dr. Irfan Syauqi Beik, it is suggested that the investment requirements of the Hajj fund be invested in economic and business sectors whose risks are minimum and manageable (manageable) and diversification management needs to be made. So to generate profits maximum, Markovic said, do not put your eggs in one basket, but lay your eggs is it in several baskets. So when there is one eggs in a broken basket, there are still eggs in another basket that can be guaranteed and certainly produce; do not fall and break. If it is associated with the management of the Hajj fund, the largest component of the Hajj fund should be invested in instruments that can offer fixed income, or sectors that are 
based on buying and selling (Istishna, Murabahah, Salam, and Bai' Muthlaq), or leasing contract (ijarah and ljarah Muntahiya Bit Tamlik), and so on.

According to Mohammad Mahbubi Ali, in his interview, he also suggested that BPKH refer to one of the well-known products in Malaysian Sharia Finance called the Is/amic Special Product. Where the management of Is/amic Special Product diversification is divided between 90 and 10 . That means $90 \%$ will go into instruments that have fixed income and the minimum risk level even though the benefits are not too high. For example, entering the property sector, building hospitality and settlements around the Grand Mosque, hospitals, and so on. While the smallest part is The remaining $10 \%$ goes to instruments that have a high level of risk, but at the same time he offers a large potential profit. So that in the worst conditions whatever the benefits obtained from the fixed income instrument are able to cover the losses of the high risk instrument which is only $10 \%$. It is a matter of investment based on mudharaba - musyaraka contract agreements, such as entering Islamic Derivatives, choosing options, taking over shares of a company, Islamic mutual funds, and so on.

Terms Fourth, there are strict audits of the investment of the Hajj fund. This means that all policies and financial management of this Hajj must have supervision from a public audit body that is credible and trustworthy. Therefore, according to Nara, an expert source, Dr. Irfan Syauqi Beik, BPKH must be supervised by a Supervisory Board which simultaneously has the task of supervising the management of financial hajj which includes the management supervision and supervision of applied sharia principles. Then you can report the results of the supervision through the media in the country, so that the report on the results of the supervision can be known by the public and the public can also supervise.

Terms Fifth, there is a security guarantee from the government (Liquid). In other words, the money must be available if needed in time. This requirement is important, considering that the Hajj fund is needed continuously. While the average need for the activities of the Indonesian pilgrimage is IDR 3.5 trillion per year. That is, the government must have a large reserve fund, at least according to $\mathrm{KH}$. Cholil Nafis, has doubled the need for organizing Hajj, to maintain the principle of liquidity, if indeed its interests are for investment in infrastructure or direct investment. To fulfill the principle of liquidity and guarantee, the government needs to involve the Deposit Insurance Corporation (LPS) to provide protection (guarantee) to the security of the managed Hajj funds. Even if necessary, involve private deposit insurance institutions, in order to ensure the security of the huge funds. 
The sixth condition, produces maximum profit. Therefore, according to Interviewees $\mathrm{KH}$. Cholil Nafis and Agustianto Mingka, the BPKH policy to invest in the pilgrimage funds owned by the congregation is considered very good if many take in the direct investment sector or the real sector. Such as the construction of infrastructure, construction of hospitals, accommodation of pilgrims in Saudi Arabia, building restaurants, buying special airlines to Saudi Arabia, and can also be used in part to procure equipment for pilgrims of Hajj and Umrah, such as turban, robes, uniforms and Ihram clothes. Currently the majority is imported from the bamboo curtain country, China. Even though it is a definite need for every pilgrim. Wallahu'alam bus shawab.

\section{Conclusions, Policy Implications and Suggestions}

\subsection{Conclusion}

From the results of the discussion above, the following looks at the results of interviews with expert resource persons consisting of a board of sharia economists, conclusions can be obtained as follows:

1. The model of muamalah covenants which basically can be applied to the management of the Hajj fund by the BPKH in terms of revenue, between the BPIH (Hajj Pilgrims) depositor and the BPKH are the Wadi'ah Yad Dhamanah contract, Mudharabah Muthlaqa, Wakalah bil Ujrah, and ljarah Maushufah contract Fi Dzimmah (IFMD). While the model-contract agreement muamalah applied by BPKH investment side / utilization of funds for investment activities are: (1) the contract of Mudharaba muthlaqa, Mudharaba muqayada, and Musharaka for -sector business sector-based profit-sharing. Like investing in fund placements in the form of Deposits, Sharia Banking Demand Deposits, Sharia Mutual Funds, and Equity Participation, and other investments. (2) ljarah contract, ljarah Muntahiya Bit Tamlik (IMBT), and Parallel ljarah, for business sectors based on fee based income (commission). These types of are used for BPKH investment activities such as in Corporate Sukuk, SBSN, SDHI, and rental of lodging services (Hostels, Hotels), Airlines, and so on. (3) The contract of Bai 'Salam, Murabahah, Istishna', and Bai' Muthlaqa. These types of are used for investment activities such as procurement (purchase) of gold, Hajj equipment (ihram cloth, Mokena, luggage bags, prayer mats, etc.), land and buildings, toll roads (property and construction), and other appropriate forms of investment with the criteria of BPKH.

2. Whereas according to the results of the interview with the resource person, it was concluded that the most appropriate model of the muamalah contract in accordance with 
sharia law was the ljarah Maushufah Fid Dzimmah contract. This is due, the main object of the pilgrimage registration carried out by pilgrims is the service of hajj departure. Where the hajj registrants make an advance payment for the purchase of the service, the new Hajj departure service will be received by the pilgrims later when the hajj quota has arrived. Because the object of the contract is a service and is still in the form of a government burden in the future to dispatch, then the right contract and in accordance with this activity is the contract of Ijarah Maushufah Fid Dzimmah.

3. The results of this study also indicate that the conditions for investing in Hajj funds according to sharia provisions are at least 6 points. (1) Fulfilling the legal aspects of positive and legal sharia law, (2) The urgent need of pilgrims in the smooth functioning of their worship, (3) Business projects that become investment objectives, there has been a process of prior business feasibility analysis that has considered everything the risk and level of return, (4) the existence of strict audit supervision of investment in the Hajj fund, (5) the existence of liquidity aspects of investment instruments, and (6) the intended business project can provide a reasonable level of profit.

\subsection{Policy Implications}

The results of this study are very useful for parties with an interest in carrying out the pilgrimage, especially the government and BPKH. Below are the policy implications of the results of this research for several institutions or related agencies.

1. For BPKH agencies it is recommended to request a review of the MUI DSN on the decision of Fatwa No.122 / DSN-MUI / II / 2018 concerning Management of BPIH and Special BPIH Based on Sharia Principles, which recommends the Wakalah bil Ujrah contract as a reference for the management of Hajj funds by BPKH. Because, in this study, the author found the most appropriate alternative contract applied, namely ljarah Maushufah Fid Dzimmah.

2. Both the wakalah bil ujrah and IMFD contract, the terms of the ujrah must be known and agreed upon by both parties at the outset ( $\mathrm{CJH}$ and BPKH). Therefore, it is recommended for the BPKH to mention the number of ujrah that will be used for operations to the congregation as the owner of legitimate funds, both in nominal form and the percentage at the beginning of the contract when depositing BPIH to BPS that has collaborated with BPKH.

3. The benefits of optimizing the management of hajj funding should be returned to the pilgrims through service is good and need meets urged the pilgrims, as set up boarding, hotel / hostel Hajj Indonesia, fulfilling the needs of catering and purchase 
airline specifically pilgrims to the departure of pilgrims Indonesia. In this way (through hajj financial management) it is able to contribute in promoting national economic growth as well as contributing to national development.

4. BPKH must learn a lot from the Tabung Haji Institute Malaysia, as the first Islamic financial institution that managed the hajj funds of the Malaysian community very well and creatively in developing its funding products and investment side.

5. BPKH in terms of investment to obtain optimal benefit value, can cooperate with the Ministry of Religion as a partner who will use BPKH investment objects such as for lodging, catering and transportation. Cooperation can also be carried out by the BPKH with the Ministry of Finance in the placement of Hajj funds on SDHI, SBSN, Sharia Treasury Bills (SPNS), both in the form of Rupiah and in $U$ \$ Dollars.

6. BPKH can also work together with Islamic Investment Managers, domestically and abroad, as partners in public fund management and issuers of Islamic investment instruments (Mutual Funds). Likewise, BPKH can also work with Sharia Securities Companies (Brokers) as partners that provide investment instruments in the primary market and secondary markets.

7. The government, in this case BPKH, can also cooperate with Islamic banking financial institutions (BUS and UUS), as recipients of BPIH deposits from pilgrims, and channel them to profitable productive sectors. In addition, BPKH can also collaborate with similar institutions that have similar characters, such as BPJS, Taspen and Pension Fund, as well as several other intermediary institutions that function as BPKH's working partners in investing.

\subsection{Suggestions}

1. Through this research, it is expected to expand academic research studies related to the management of Hajj finances. The priority of problems and solutions of financial management of this Hajj is like being able to provide appropriate input to all relevant parties, what problems should be first resolved and which solutions are the most appropriate to be implemented.

2. It is hoped that in the future, there will be a more detailed and detailed similar study on the management of Hajj funds in other Muslim countries, then make a comparison table between similar institutions, and take some positive points that can be applied in Indonesia according to the character and culture in Indonesia.

3. The author realizes there are still many shortcomings and limitations in this study. For this reason, the authors hope that this research can be refined and further developed 
by the researchers furthermore related to the research methodology using quantitative approaches such as Vector Auto Regression - Vector Error Correction Model (VARVECM), Structural Equation Modeling (SEM) or Data Envelopment Analysis (DEA), or qualitative methods such as Analytic Network Process (ANP).

[1] Al-Qur'an Al-Karim

[2] Sunnah of An-Nabawiyyah.

[3] AAOIFI, (2013). Al-Ma'ayir ash-Syar'iyah , Bahrain, Sharia Standard No. 34 ljaratu al-Ashkhas .

[4] Abimanyu, A. (2014). Management of Previous, Present and Future Hajj Funds Hajj Reality Magazine Edition 01 April 2014.

[5] Al-Qaradaghi, Dr. Ali Muhyiddin, (2008). Al-ljarah 'Ala Manafi' Al-Ashkhas. Paper presented at the 2008 European Fatwa Assembly in France.

[6] Al-Qasimi, Badr al-Hasan, (2009), Al-Ijarah Maushufah Fid Dzimmah Lil Khadamat Ghair al- Mu'ayyanah, Dairah as-Syu'un al-Islamiyyah wa 'Amal al-Khoiriy, Dubai.

[7] Al-Handawi, Salim Jamal, (2012). Al-Hukmu Idza Ta'aradhat Mafsadatani , Paper.

[8] Antonio, Dr. Muhammad Syafi'i, (2006). Economy of Hajj: The Neglected Fortune. Tazkia Islamic Finance \& Business Journal, Vol. 1, Bogor.

[9] Ash-Shiddieqy, Prof. Dr. Teungku Muhammad Hasbi, (2009) Introduction to Muamalah Fiqh, Revised Edition, Rizki Putra Library, Semarang.

[10] Az Zuhaili, Dr.Wahbah. (2001). Al-Fiqh al-Islami Wa Adillatuh . Vol 5. Cet. 4, Damascus Daar al- Fikr. Lebanon.

[11] Az-Zarqa, Mustafa Ahmad. (1968). Al-Fiqh al-Islami fi Tsaubihi al-Jadid : al-Madkhal al-Fiqh al- 'Amm . I. Beirut: Dar al-Fikr.

[12] Bani Hani, Hussein. (2009). Hawafiz al-Istitsmaar Fi al-Nidham al-lqtishad al-Islamiy , daar al-Kindi, Urdun.

[13] Ghuddah, DA (2007). Dhawabit Al-ljarah Al-Khadamat wa Thadbiqat Al-ljarah AlMaushufah Fi Zimmah . (pp. 87-101). Al- B araka Banking Group, Jeddah.

[14] Haura, Ari, (2010) Management of Hajj Funds in Indonesian Hajj Fund Sukuk (SDHI). Essay. Syarif Hidayatullah UIN Jakarta.

[15] Hammad, Nazih. (2005). Al-'Uqûd al-Murakkabah fî al-Fiqh al-Islami . Cet. number 1. Damascus: Dar al-Qalam.

[16] Ibnu Jazi, Muhammad bin Ahmad bin Muhammad,(2009) Qawanin al-Ahkam alSyar'iyyah wa masail al-Furu 'al-Fiqhiyyah, Maktabah Jami'ah al-Malik Saud, Arabia. 
[17] Kalono, Sri \& Setiaji, B. (2010) Comparative Study of Indonesian-Malaysian Cost and Hajj Services. Paper.

[18] Mannan, Dr. Mohammad Abdul, (1996). Islamic socioeconomic Institutions and mobilization of resources with special Reference Management of Malaysia. Journal of Islamic Research and Training Institute of Islamic Development Bank, Jeddah Saudi Arabia.

[19] Masyhur, Amirah Abdul Lathief, (2009). Al-Istitsmaar fi al-lqtishaad al-Islamiy, Maktabah Madbuli, Qahirah, Egypt.

[20] Moleong, Lexy J. (2007). Qualitative Research Methodology. Publisher: Teenager Rosdakarya, Bandung.

[21] Nassar, Ahmad Muhammad Mahmud, (2009), Dhawabit Al-ljarah Al-Mausufah Fi Dzimmah wa Thathbiqatiha fi Tamwil Al-Khadamat Fi al-Muassasat al-Maliyyah alIslamiyyah. Print: Nadwah al-Barakah .

[22] Natsir, Mohammad. (2005). Research Methods, Ghalia Indonesia, Bogor.

[23] Government Regulation Number 5 Year 2018 concerning Implementation of Law No. 34 of 2014 concerning Financial Management of Hajj.

[24] Presidential Regulation Number 110 of 2017 concerning BPKH

[25] Minister of Religion Regulation No. 14 of 2012 concerning the Implementation of Regular Hajj

[26] Minister of Religion Regulation Number 23 of 2016 Concerning the Implementation of Special Hajj.

[27] BPKH Strategic Plan for 2018 - 2022

[28] Sanu, Dr. Abu Muhammad Qutb Musthofa, (2000). Al-Istitsmar Ahkamuhu wa Dhawabituhu fi al- Figh al-Islamiy, Daar an-Nafais , Urdun.

[29] Septiana, Nurul Izzati, (2015). Construction of the Financial Management Model of Hajj on Is/amic Banks in Indonesia. Thesis. Masters in Islamic Economics, UIN Sunan Kalijaga Yogyakarta. Shuhaimi,

[30] Mohd Bin Haji Ishak, (2011). Tube Hajj and Islamic Financial Institution for Sustainable Economic Development. IPEDR Journal of Historical Social Sciences vol.17. Paper.

[31] Subadi, (2013). Implementation of the Hajj Service Policy at the Office of the Ministry of Religion of the Regency of Riau Islands Province. Paper.

[32] Syahroni, Dr. Oni, M, (2012), Ownership of Hajj Jamaah Deposits According to Islamic Sharia, the paper was written as material for discussion at the ljtima Sanawi Fatwa Commission held in Tasikmalaya. 
[33] Law of the Republic of Indonesia Number 13 of 2008 concerning the Implementation of Hajj. Law of the Republic of Indonesia Number 17 of 1999 concerning Implementation of Hajj.

[34] Law of the Republic of Indonesia Number 34 of 2014 concerning Management of Financial Hajj.

[35] Yahaya, Habibah, et all (2016), " Tabung Haji Malaysia as a World Role Model of Islamic Management Institutions "International Journal of Business and Management Invention ISSN, Volume 5 issue 11, 2016.

[36] https://news.detik.com/berita/d-4040792/kemenag-permanenkan-kuota-hajitambahan-hadiah-dari-raja-salman, accessed on August 14, 2018.

[37] https://tirto.id/di-mana-saja-dana-haji-ditempat-ct8V (accessed on August 25, 2018)

[38] Moses, Dr. Muhammad Yusuf, (2014), Introduction to Islamic Jurisprudence Studies , p. 17, Publisher: Reader Al Kautsar, Jakarta.

[39] Abdurrauf. Journal entitled: Application of contract theory to Islamic banking, p. 13 [40] Ibnu Taimiyah, (2004). Majmu 'Fatawa, Vol. 28, p. 386. Prints: Khadimul Haramain al-Syarifain Al-Malik Fahd Bin Abdul Aziz, Saudi Arabia.

[41] As-Suyuthiy, (2001). Al-Asybah wa an-Nadhair Fi Fiqh as-Syafi'i, p. 87. Daar al-Kotob al- Ilmiyyah, Beirut Lebanon.

[42] Dr. Salim Jamal al-Handawi, (2012), Al-Hukmu Idza Ta'aradhat Mafsadatani , Paper. (from Source: http://www.alukah.net/sharia/0/41644/ (accessed on September 5, 2018).

[43] Al-Lathif, Abdul Rahman bin Salih al-Abdu, (2003). al-Qawa'id wa al-Dhawabidh al-Fiqhiyyah al-Mutadhamminah li al-Taisir, Vol. 2, p. 89. Prints: Al-Mamlakah Saudi Arabia.

[44] As-Suyuthiy, (2001). Al-Asybah wa an-Nadhair Fi Fiqh as-Syafi'i , p. 83. Daar alKotob al- Ilmiyyah, Beirut Lebanon.

[45] Ahmad Azhar Basir, 1998. Muamalat's Law Principles , p. 44. Prints: Ull Faculty of Law, Yogyakarta.

[46] "Already the Wakalah Agreement for the Management of BPIH Doesn't Have to Be a Community Service Permit Again", https://kemenag.go.id/berita/read/505045/ sudah-Contracts-wakalah--management-bpih-tak-harus-izin-jemaah-agi, accessed on August 14, 2018.

[47] Syahroni, Dr. Oni, M, (2012), Ownership of Hajj Jamaah Deposits According to Islamic Sharia, the paper was written as material for discussion at the ljtima Sanawi Fatwa Commission held in Tasikmalaya. 
[48] Ibn Qudamah, Al-Mughni , Vol. 7, p. 204, Daar al-Fikr, Beirut, Damascus.

[49] Ibn Jazi, Muhammad bin Ahmad bin Muhammad, (2009), Qawanin al-Ahkam alSyar'iyyah wa masail al-Furu 'al-Fiqhiyyah , P. 345, Maktabah Jami'ah al-Malik Saud, Arabia.

[50] An-Nawawi, Abi Zakariya Yahya bin Syaraf ad-Dimasyqy, (1990). Raudhah atThalibin , Vol. 4, p. 330-332, Daar alam al-Maktabat, Beirut, Lebanon.

[51] Al-Mawardi, Al-Hawi Fi Fiqh As-Syafi'l, Cet. 1, (1994), Daar al-Kotob al-Ilmiyah , Beirut, Vol. 5, p. 363.

[52] Al-'Bbbadi, Sirajuddin Umar Bin Abdullah Bin Qasim, (2014). " Hasyiyah al-'Ubbadiy 'ala Qawa'id az-Zarkasyi " p. 160, Maktabah al-Azhar, Egypt. 